\title{
Granulocyte Colony-stimulating Factor Producing Oropharyngeal Squamous Cell Carcinoma
}

\author{
GREGORY SCHURMANN ${ }^{1}$, MARTIN ZWEIFEL ${ }^{1}$, ROLAND GIGER ${ }^{2}$, TILMAN T. RAU ${ }^{3}$, \\ SARAH VINZENS ${ }^{4}$, MATTHIAS S. DETTMER ${ }^{3}$ and YOJENA KURIAN ${ }^{1}$ \\ ${ }^{1}$ Department of Medical Oncology, Biel-Bienne, Switzerland; \\ ${ }^{2}$ Department of Otorhinolaryngology, Head and Neck Surgery, Inselspital, \\ Bern University Hospital, University of Bern, Bern, Switzerland; \\ ${ }^{3}$ Institute of Pathology, University of Bern, Bern, Switzerland; \\ ${ }^{4}$ Onkologie, Spital Thun, Thun, Switzerland
}

\begin{abstract}
Case Report: We report on the case of a 47-year old woman with granulocyte colony-stimulating factor $(G-$ CSF)-producing relapsed oropharyngeal squamous cell cancer. Palliative immunotherapy with nivolumab was started. Absolute neutrophilic count increased during the course of immunotherapy and correlated with tumour progression. Under chemotherapy with weekly paclitaxel, dramatic tumour regression and decreasing absolute neutrophilic count were noted. G-CSF concentration in serum increased from 4.77 to $9.61 \mathrm{pg} / \mathrm{ml}$ during the final phase of tumour progression. Immunohistochemical staining of the initial biopsies showed that some of the tumour cells as well as infiltrating cells stained positively for G-CSF, and some of the tumour cells even stained positively for the $G$ CSF receptor. Conclusion: Leukaemoid reaction in malignant disease with increased neutrophilic granulocytes has been shown to correlate with dismal prognosis in other tumours. The role of G-CSF in progression and prognosis of head and neck squamous cell carcinomas is still unclear but in patients with these tumours there seems also to be a correlation between elevated G-CSF and poor prognosis. Further systematic evaluation of G-CSF secretion in this tumour entity should clarify the role and potential treatment possibilities for these tumours.
\end{abstract}

This article is freely accessible online.

Correspondence to: Martin Zweifel, MD, Ph.D., Spitalzentrum Biel, 2501 Biel-Bienne, Switzerland. Tel: +41 323243662, Fax: +41 323243799, e-mail: martin.zweifel@szb chb.ch

Key Words: Oropharyngeal carcinoma, granulocyte colonystimulating factor, leukocytosis, neutrophilic granulocyte, paraneoplastic syndrome, immunotherapy.
There are many reports on granulocyte-colony stimulating factor (G-CSF)-producing tumours in the literature but only a few reported cases of this entity in head and neck carcinoma. Here we describe the case of a patient with a G-CSFproducing oropharyngeal tumour, discussing the outcome and poor prognosis associated with this tumour entity.

\section{Case Report}

We report on the case of a 47-year old woman with granulocyte colony-stimulating factor (G-CSF)-producing relapsed oropharyngeal squamous cell cancer after radical chemoradiation.

The patient presented to her general practitioner because of dysphagia and enlarged right cervical lymph nodes. Biopsy of an oral lichenoid appearing lesion was performed. Histology revealed a human papilloma virus-negative squamous cell carcinoma. Magnetic resonance imaging (MRI) showed a lesion in the right soft palate with extension to the right retromolar trigonum and suspected maxillar infiltration. Positron emission tomography-computed tomography confirmed bone infiltration of the alveolar process and the maxillary sinus. Field mapping biopsies were performed and confirmed infiltration of the uvula, right soft palate, and the right retromolar trigonum. The TNM classification (1) was cT4bcN2ccM0, tumour grade 2 . Radical chemoradiation was performed for three cycles of platinum chemotherapy combined with radiotherapy for a total dose of $70 \mathrm{~Gy}$ in 35 fractions. However, positronemission tomography-computed tomography revealed a metabolically active mass with central necrosis in the place of the previous tumour, thus confirming relapse. MRI confirmed a persisting tumour lesion of $3.5 \mathrm{~cm} \times 2 \mathrm{~cm}$ in the right retromolar trigonum (Figure 1A). Histology upon rebiopsy confirmed relapse of disease. 


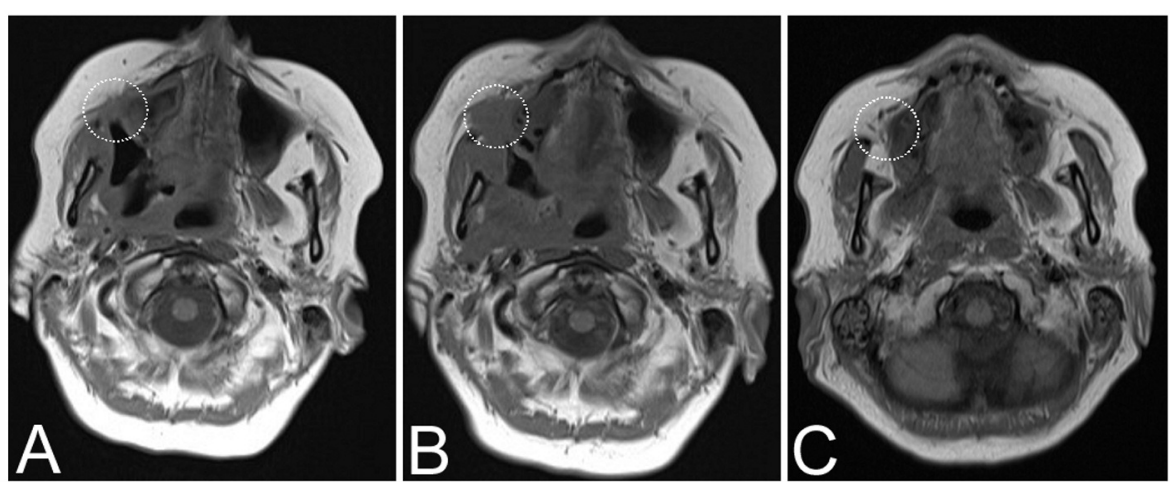

Figure 1. Magnetic resonance imaging of a 47-year-old woman diagnosed with relapsed oropharyngeal squamous cell cancer. A 3.5×2-cm lesion in the right retromolar trigonum (white dotted circle) can be seen $(A)$, which increased in size during immunotherapy with nivolumab for seven cycles (i.e. 4 months) $(B)$ and then diminished in size within 2 weeks (i.e. 3 weekly administrations of paclitaxel along with $8 \mathrm{mg}$ dexamethasone) (C).

The tumour was deemed not operable and palliative immunotherapy with nivolumab at $3 \mathrm{mg}$ per $\mathrm{kg}$ body weight was started. The absolute neutrophilic count (ANC) was $4.8 \times 10^{6} / 1$ at that time. However, after initial subjective relief of symptoms, immunotherapy was stopped because of tumour growth after seven cycles (Figure 1B). An increase of ANC of $18.02 \times 10^{6} / 1$ was noted, consisting exclusively of mature neutrophilic granulocytes without evidence of infection (Figure 2). Third-line chemotherapy with weekly paclitaxel at $90 \mathrm{mg} / \mathrm{m}^{2}$ and $8 \mathrm{mg}$ dexamethasone as premedication was started. After 2 weeks, dramatic tumour regression was noted clinically and upon MRI (Figure 1C), associated with decreasing ANC (Figure 2).

However, paclitaxel had to be stopped due to side-effects (i.e. worsening condition, anorexia) and the white blood cell count (WBC) was noted to be increasing.

A trial with nivolumab as rechallenge was performed. The dramatic response of the tumour to paclitaxel and dexamethasone within only 2 weeks left a faint hope that in fact pseudo-progression (i.e. infiltrating cells of the immune system) might have been the reason for increasing tumour size rather than tumour progression. A distinction between the two is not possible to make radiologically. After starting nivolumab again, the ANC decreased but the G-CSF concentration in serum increased from 4.77 to $9.61 \mathrm{pg} / \mathrm{ml}$. The patient's condition deteriorated and treatment had to be stopped entirely. The patient died unfortunately, 1.5 years after primary diagnosis.

Immunohistochemical staining of the initial biopsies showed that some of the tumour cells as well as the infiltrating cells stained positively for G-CSF (Figure 3B), and some of the tumour cells even stained positively for the G-CSF receptor (G-CSFR) (Figure 3C).

\section{Discussion}

Leukaemoid reaction in malignant disease with increased neutrophilic granulocytes in the absence of leukaemia and infection is a well-known phenomenon (2). It has been shown that this may be due to secretion of G-CSF by the tumour, known as paraneoplastic syndrome, and that the prognosis of patients with tumour with increased neutrophilic granulocytes is dismal (3-5). Under physiological conditions, macrophages and monocytes are the cells which secrete GCSF but it has been shown that tumour cells are capable of adopting this role (6). While ectopic production of G-CSF has been demonstrated for a vast variety of tumour types, only data of eight case reports are available on paraneoplastic G-CSF secretion in head and neck squamous cell carcinoma (7-14) (Table I).

In these published cases, and including our case, female patients were slightly over-represented (56\%) compared with men (44\%). The mean age was 59 years at the time of diagnosis. Outcome was poor, with patients dying on average 10 months after diagnosis (1.5 to 18 months).

The average $\mathrm{WBC}$ at the time of diagnosis in these patients was $35.8 \times 10^{6} / 1$, which is roughly 4 -fold the upper limit of normal. G-CSF was increased in seven cases, with an average of $197 \mathrm{pg} / \mathrm{ml}$.

Histologically, all tumours were shown to be squamous cell carcinomas. In most studies, G CSF was immunohistochemically confined to tumour cells. However, one study reported a negative result for G-CSF immunohistochemical staining (9) and in our study, as well as some of the tumour cells, some of the infiltrating leukocytes stained positiveIy for G-CSF. There has been speculation that the rapid secretion of G-CSF from tumour cells may lead to negative staining results (9). Indeed, other 


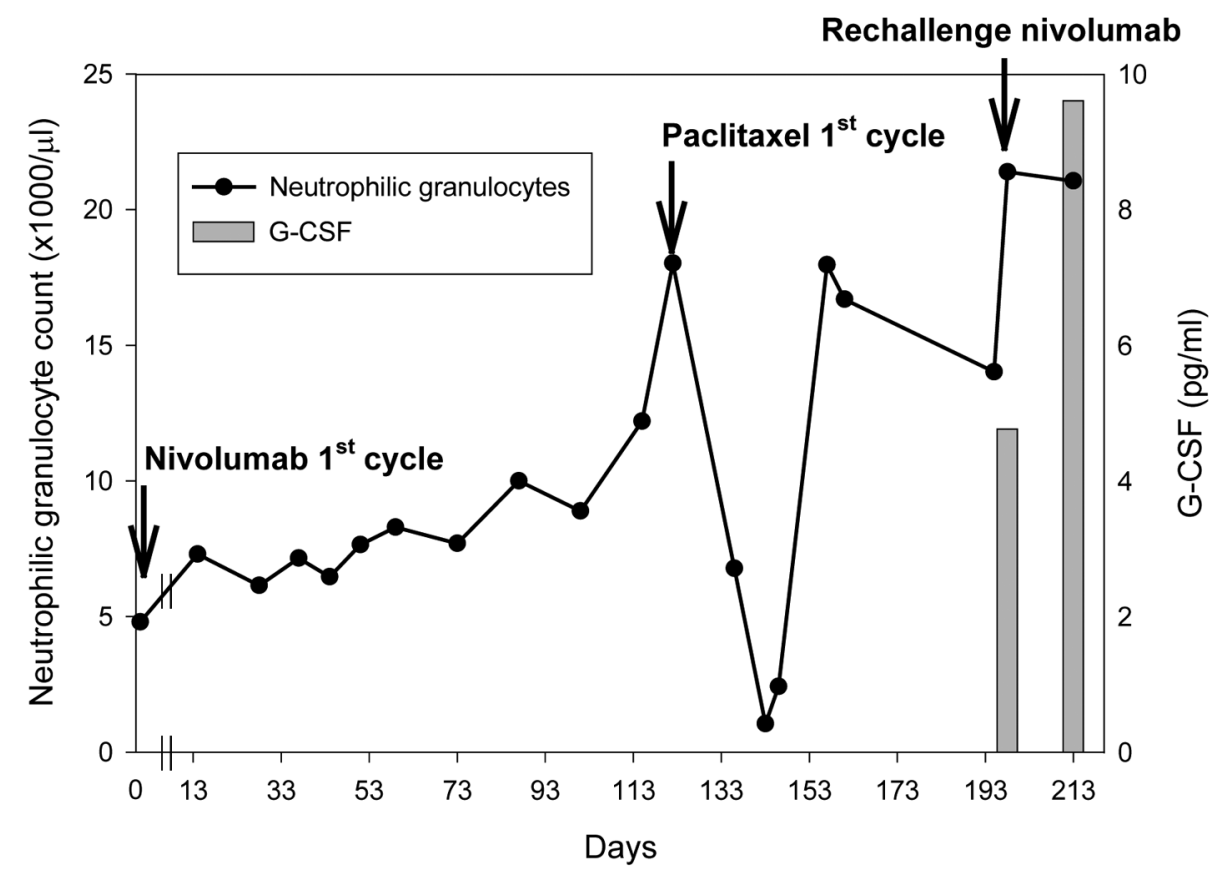

Figure 2. Neutrophilic granulocyte count (absolute neutrophilic count, ANC) and serum granulocyte colony-stimulating factor (G-CSF) concentration during the course of the disease.

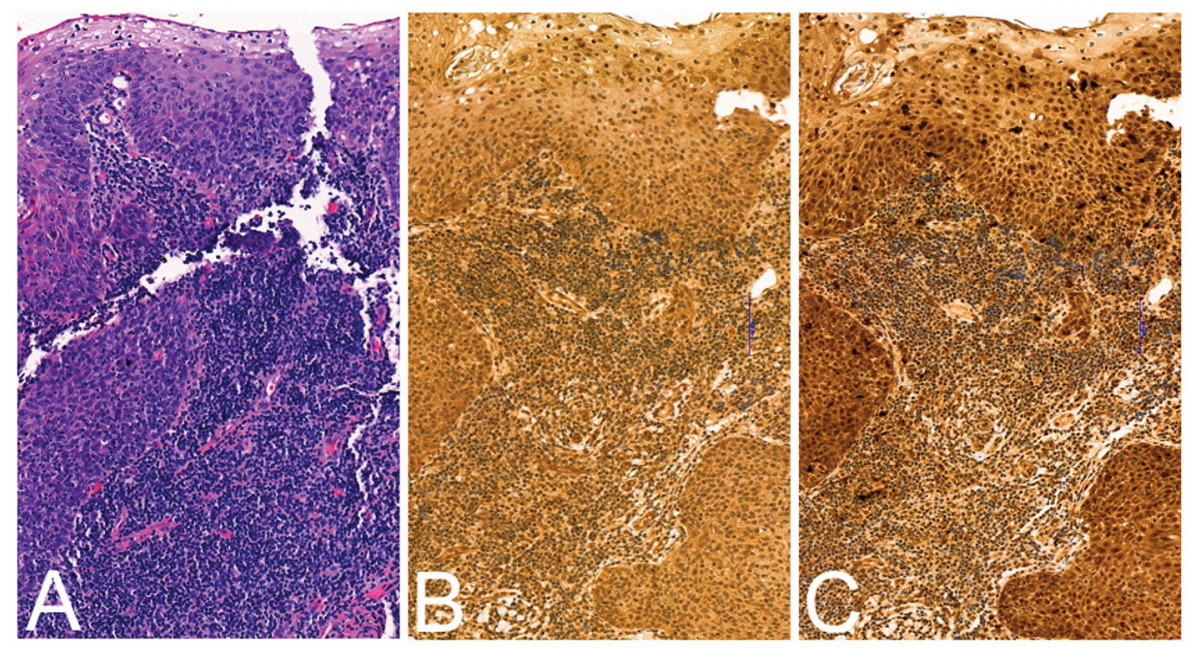

Figure 3. Histochemistry and immunohistochemistry of serial sections (20x). A: Squamous cell carcinoma was seen upon haematoxylin-eosin staining. B: Tumour cells and some of the infiltration leukocytes stained positively for granulocyte colony-stimulating factor. C: Some of the tumour cells stained positively for granulocyte colony-stimulating factor receptor.

tumours associated with increased serum G-CSF concentration showed negative immunohistochemical staining in tumour cells $(15,16)$. However, serum G-CSF and WBC increase in parallel with tumour growth was reported in the majority of all published cases.
Moreover, in our patient, we noticed that ANC seemed to correlate with tumour growth. Interestingly, immunohistochemical localization of G-CSF was not only confined to tumour cells but was also found in tumour-infiltrating cells. This is a finding which has already been described in 
in vivo $35: 1785-1790(2021)$

Table I. Reported cases of granulocyte colony-stimulating factor (G-CSF)-producing head and neck squamous cell carcinomas.

\begin{tabular}{|c|c|c|c|c|c|c|c|c|c|}
\hline Ref & $\begin{array}{l}\text { Age, } \\
\text { years }\end{array}$ & Gender & Histology & $\begin{array}{l}\text { WBC, } \\
\times 10^{6} / 1\end{array}$ & $\begin{array}{l}\text { ANC, } \\
\times 10^{6} / 1\end{array}$ & $\begin{array}{l}\mathrm{G}-\mathrm{CSF}, \\
\mathrm{pg} / \mathrm{ml}\end{array}$ & $\begin{array}{c}\text { Cellular localization } \\
\text { of G-CSF }\end{array}$ & Treatment & $\begin{array}{l}\text { Survival } \\
\text { (months) }\end{array}$ \\
\hline (13) & 61 & M & $\begin{array}{l}\text { SCC of the } \\
\text { tongue }\end{array}$ & 96.2 & N/A & 204 & Tumour cells & $\begin{array}{l}\text { Subtotal glossectomy } \\
\text { with reconstruction. } \\
\text { No chemoradiation }\end{array}$ & 12 \\
\hline (10) & 57 & M & $\begin{array}{l}\text { SCC of the } \\
\text { tongue }\end{array}$ & 22.7 & N/A & $>50$ & Tumour cells & $\begin{array}{l}\text { Neoadjuvant chemoradiation, } \\
\text { then glossectomy, segmental } \\
\text { mandibulectomy and modified } \\
\text { neck dissection followed } \\
\text { by adjuvant chemoradiation }\end{array}$ & 4.5 \\
\hline (14) & 50 & $\mathrm{~F}$ & $\begin{array}{l}\text { SCC of lower } \\
\text { gums }\end{array}$ & 32 & N/A & 250 & Tumour cells & $\begin{array}{l}\text { Surgery, then chemoradiation. } \\
\text { Left mandibular and supra- } \\
\text { omohyoid resection upon relapse }\end{array}$ & 13 \\
\hline (9) & 78 & M & $\begin{array}{l}\mathrm{SCC} \text { of the } \\
\text { tongue }\end{array}$ & 21.7 & $86.4 \%$ & 117 & $\begin{array}{l}\text { Negative in } \\
\text { tumour cells }\end{array}$ & $\begin{array}{l}\text { Oral chemotherapy. } \\
\text { Patient declined surgery, } \\
\text { radio- and chemotherapy }\end{array}$ & 12 \\
\hline (11) & 81 & $\mathrm{~F}$ & $\begin{array}{c}\text { SCC of the } \\
\text { buccal mucosa }\end{array}$ & 41.8 & Increased & N/A & Tumour cells & $\begin{array}{l}\text { Chemoradiation and partial } \\
\text { resection of the cheek and } \\
\text { radical neck dissection }\end{array}$ & 6 \\
\hline (12) & 58 & $\mathrm{~F}$ & $\begin{array}{l}\text { SCC of the } \\
\text { tongue }\end{array}$ & 21.38 & $84 \%$ & 663 & Tumour cells & $\begin{array}{l}\text { Partial glossectomy and } \\
\text { bilateral neck dissection }\end{array}$ & 1.5 \\
\hline (7) & 57 & $\mathrm{~F}$ & $\begin{array}{c}\text { SCC of } \\
\text { hypopharynx }\end{array}$ & 46.3 & $89 \%$ & 111 & Tumour cells & $\begin{array}{l}\text { Radiation with } 4 \text { cycles } \\
\text { of cisplatin chemotherapy }\end{array}$ & 12 \\
\hline (8) & 45 & M & SCC (CUP & 16.2 & N/A & 173 & Tumour cells & $\begin{array}{l}\text { Palliative radiotherapy } \\
\text { (not operable, no chemo } \\
\text { due to renal failure) }\end{array}$ & N/A \\
\hline Our case & 47 & $\mathrm{~F}$ & $\begin{array}{l}\text { SCC of the } \\
\text { oropharynx }\end{array}$ & 23.53 & $90.9 \%$ & 9.61 & $\begin{array}{c}\text { Tumour cells and } \\
\text { some infiltrating cells }\end{array}$ & $\begin{array}{c}\text { Not operable. } \\
\text { Chemoradiation, then } \\
\text { immunotherapy and } \\
\text { paclitaxel chemotherapy } \\
\text { upon relapse }\end{array}$ & 18 \\
\hline
\end{tabular}

ANC: Absolute neutrophil count; CUP: cancer of unknown primary; F: female; G-CSF: granulocyte colony-stimulating factor; M: male; N/A: not available; SCC: squamous cell carcinoma; WBC: white blood cell count.

other types of tumours (16). Staining was positive for GCSFR in some tumour cells. The expression of both G-CSF and G-CSFR by the same cells in G-CSF-producing tumours has only been described twice, in a case of hepatocellular carcinoma (17), and a case of anaplastic pancreatic carcinoma (16)

In order to secrete G-CSF, cells are believed to have appropriate stimulation by tumour necrosis factor; interleukins 1, 3, and 4; granulocyte macrophage-colony stimulating factor; and interferon- $\gamma$ (18-24). For G-CSFproducing tumours, one could speculate as to whether some tumour cells might become sensitive to an appropriately stimulating factor eliciting G-CSF secretion, or might be capable of producing G-CSF without appropriate stimulation, and whether infiltrating macrophages might produce G-CSF either through stimulation by tumour cells or as a bystander effect.

The findings of our case, compared to the other cases reported, suggest that these tumours seem to exhibit autocrine stimulation by secreting G-CSF and expressing G-
CSFR, hence increasing tumour growth/progression and explaining the dismal prognosis of G-CSF-producing tumours. In fact, there is evidence that this mechanism has a role in colon adenocarcinoma (25) and small-cell lung cancer cell lines in vitro (26). However, other studies did not find evidence for tumour stimulation through G-CSF (27).

The role of G-CSF in progression and prognosis of head and neck squamous cell carcinomas is still unclear but in these tumour types, there also seems to be a correlation between elevated G-CSF and poor prognosis. Increased rates of recurrence and metastasis were found in patients whose primary head and neck squamous cell carcinomas secreted granulocyte-macrophage-CSF (28).

In summary, we describe a case of a 47-year old woman with relapsed oropharyngeal squamous cell carcinoma and with only a short-lived response to immuno- and chemotherapy. A G-CSF-stimulated increase in ANC correlated with the clinical course and might explain the aggressive behaviour of the tumour and our patient's dismal prognosis. Further systematic evaluation of G-CSF secretion 
in this tumour entity should clarify the role and potential treatment possibilities for these tumours.

\section{Conflicts of Interest}

The Authors declare no conflicts of interest.

\section{Authors' Contributions}

G.S., M.Z., R.G., S.V. and Y.K. performed all literature searches, designed the table and figures, and wrote the article. T.T.R. and M.D. performed immuno/histochemical stainings, and produced their figures and explanations.

\section{References}

1 Eisenhauer EA, Therasse P, Bogaerts J, Schwartz LH, Sargent D, Ford R, Dancey J, Arbuck S, Gwyther S, Mooney M, Rubinstein L, Shankar L, Dodd L, Kaplan R, Lacombe D and Verweij J: New response evaluation criteria in solid tumours: Revised RECIST guideline (version 1.1). Eur J Cancer 45(2): 228-247, 2009. PMID: 19097774. DOI: 10.1016/j.ejca.2008.10.026

2 Granger JM and Kontoyiannis DP: Etiology and outcome of extreme leukocytosis in 758 nonhematologic cancer patients: A retrospective, single-institution study. Cancer 115(17): 39193923, 2009. PMID: 19551882. DOI: $10.1002 /$ cncr. 24480

3 Casbon AJ, Reynaud D, Park C, Khuc E, Gan DD, Schepers K, Passegué E and Werb Z: Invasive breast cancer reprograms early myeloid differentiation in the bone marrow to generate immunosuppressive neutrophils. Proc Natl Acad Sci USA 112(6): E566-E575, 2015. PMID: 25624500. DOI: 10.1073/pnas.14249 27112

4 Waight JD, Hu Q, Miller A, Liu S and Abrams SI: Tumorderived G-CSF facilitates neoplastic growth through a granulocytic myeloid-derived suppressor cell-dependent mechanism. PLoS One 6(11): e27690, 2011. PMID: 22110722. DOI: 10.1371 /journal.pone. 0027690

5 Templeton AJ, McNamara MG, Šeruga B, Vera-Badillo FE, Aneja P, Ocaña A, Leibowitz-Amit R, Sonpavde G, Knox JJ Tran B, Tannock IF and Amir E: Prognostic role of neutrophilto-lymphocyte ratio in solid tumors: A systematic review and meta-analysis. J Natl Cancer Inst 106(6): dju124, 2014. PMID: 24875653. DOI: $10.1093 /$ jnci/dju124

6 Sakka V, Tsiodras S, Giamarellos-Bourboulis EJ and Giamarellou H: An update on the etiology and diagnostic evaluation of a leukemoid reaction. Eur J Intern Med 17(6): 394 398, 2006. PMID: 16962944. DOI: 10.1016/j.ejim.2006.04.004

7 Tamura K, Yoshinaga T, Tanino M, Kimura T, Yamada N, Nishimura M, Fukuda S, Nishihara H, Shindoh M and Tanaka S: Hypopharyngeal squamous cell carcinoma producing both granulocyte colony-stimulating factor and parathyroid hormonerelated protein. Pathol Int 58(10): 652-656, 2008. PMID: 18801086. DOI: 10.1111/j.1440-1827.2008.02285.x

8 Toyoda M, Chikamatsu K, Sakakura K, Fukuda Y, Takahashi K, Miyashita M, Shimamura K and Furuya N: A case of squamous cell carcinoma of the head and neck producing granulocytecolony stimulating factor with marked leukocytosis. Auris Nasus Larynx 34(2): 267-271, 2007. PMID: 17097253. DOI: 10.1016/j.anl.2006.07.014
9 Kuroshima T, Wada M, Sato T, Takano M and Makino S: G-CSF producing oral carcinoma with diffuse uptake of FDG in the bone marrow: A case report. Oncol Lett 15(1): 1241-1245, 2018. PMID: 29399178. DOI: 10.3892/ol.2017.7422

10 Kaneko N, Kawano S, Matsubara R, Goto Y, Jinno T, Maruse Y, Sakamoto T, Hashiguchi Y, Iida M and Nakamura S: Tongue squamous cell carcinoma producing both parathyroid hormonerelated protein and granulocyte colony-stimulating factor: A case report and literature review. World J Surg Oncol 14(1): 161, 2016. PMID: 27316348. DOI: 10.1186/s12957-016-0918-1

11 Matsuo K, Ishibashi Y, Kobayashi I, Ozeki S, Ohishi M, Tange T, Hirata J, Kiyoshima $\mathrm{T}$ and Sakai $\mathrm{H}$ : New human oral squamous carcinoma cell line and its tumorigenic subline producing granulocyte colony-stimulating factor. Jpn J Cancer Res 85(12): 1257-1262, 1994. PMID: 7531680. DOI: 10.1111/j.1349-7006.1994.tb02938.x

12 Shimamoto H, Hirota Y, Kashima Y, Kinoshita N, Yokokawa M, Ikeda $\mathrm{T}$ and Harada $\mathrm{H}$ : Granulocyte colony-stimulating factorproducing squamous cell carcinoma of the tongue exhibiting characteristic fluorine-18 deoxyglucose accumulation on positron emission tomography-computed tomography: A case report. World J Clin Cases 8(9): 1666-1673, 2020. PMID: 32432145. DOI: 10.12998/wjcc.v8.19.1666

13 Horii A, Shimamura K, Honjo Y, Mitani K, Miki T, Takashima S and Yoshida J: Granulocyte colony stimulating factor-producing tongue carcinoma. Head Neck 19(4): 351-356, 1997. PMID: 9213115. DOI: 10.1002/(sici)1097-0347(199707)19:4<351::aidhed15>3.0.co;2-c

14 Kobayashi J, Miyazaki A, Yamamot T, Nakamori K, Suzuki R, Kaneko T, Suzuki N and Hiratsuka H: Granulocyte colonystimulating factor-producing squamous cell carcinoma of the lower gingiva: a case report. Head Neck Oncol 4: 35, 2012. PMID: 22713692. DOI: 10.1186/1758-3284-4-35

15 Kawaguchi M, Asada Y, Terada T, Takehara A, Munemoto Y, Fujisawa K, Mitsui T, Iida Y, Miura S and Sudo Y: Aggressive recurrence of gastric cancer as a granulocyte-colony-stimulating factor-producing tumor. Int J Clin Oncol 15(2): 191-195, 2010. PMID: 20179985. DOI: 10.1007/s10147-010-0023-3

16 Vinzens S, Zindel J, Zweifel M, Rau T, Gloor B and Wochner A: Granulocyte colony-stimulating factor producing anaplastic carcinoma of the pancreas: Case report and review of the literature. Anticancer Res 37(1): 223-228, 2017. PMID: 28011495. DOI: 10.21873 /anticanres.11310

17 Kohno M, Shirabe K, Mano Y, Muto J, Motomura T, Takeishi K, Toshima T, Yoshimatsu M, Ijichi H, Harada N, Aishima S, Uchiyama H, Yoshizumi T, Taketomi A and Maehara Y: Granulocyte colony-stimulating-factor-producing hepatocellular carcinoma with extensive sarcomatous changes: report of a case. Surg Today 43(4): 439-445, 2013. PMID: 22638568. DOI: $10.1007 / \mathrm{s} 00595-012-0202-0$

18 Koeffler HP, Gasson J, Ranyard J, Souza L, Shepard M and Munker R: Recombinant human TNF alpha stimulates production of granulocyte colony-stimulating factor. Blood 70(1): 55-59, 1987. PMID: 2439155

19 Fibbe WE, van Damme J, Billiau A, Goselink HM, Voogt PJ, van Eeden G, Ralph P, Altrock BW and Falkenburg JH: Interleukin 1 induces human marrow stromal cells in long-term culture to produce granulocyte colony-stimulating factor and macrophage colony-stimulating factor. Blood 71(2): 430-435, 1988. PMID: 2447983. 
20 Zsebo KM, Yuschenkoff VN, Schiffer S, Chang D, McCall E, Dinarello CA, Brown MA, Altrock B and Bagby GC Jr: Vascular endothelial cells and granulopoiesis:Interleukin-1 stimulates release of G-CSF and GM-CSF. Blood 71(1): 99-103, 1988. PMID: 3257150.

21 Oster W, Lindemann A, Mertelsmann R and Herrmann F: Granulocyte-macrophage colony-stimulating factor (CSF) and multilineage CSF recruit human monocytes to express granulocyte CSF. Blood 73(1): 64-67, 1989. PMID: 2642718.

22 Wieser M, Bonifer R, Oster W, Lindemann A, Mertelsmann R and Herrmann F: Interleukin-4 induces secretion of CSF for granulocytes and CSF for macrophages by peripheral blood monocytes. Blood 73(5): 1105-1108, 1989. PMID: 2467700.

23 Vellenga E, Rambaldi A, Ernst TJ, Ostapovicz D and Griffin JD: Independent regulation of M-CSF and G-CSF gene expression in human monocytes. Blood 71(6): 1529-1532, 1988. PMID: 2453227.

24 Herrmann F, Cannistra SA and Griffin JD: T cell-monocyte interactions in the production of humoral factors regulating human granulopoiesis in vitro. J Immunol 136(8): 2856-2861, 1986. PMID: 3082974.

25 Berdel WE, Danhauser-Riedl S, Steinhauser G and Winton EF: Various human hematopoietic growth factors (interleukin-3, GM-CSF, G-CSF) stimulate clonal growth of nonhematopoietic tumor cells. Blood 73(1): 80-83, 1989. PMID: 2462944.
26 Avalos BR, Gasson JC, Hedvat C, Quan SG, Baldwin GC, Weisbart RH, Williams RE, Golde DW and DiPersio JF: Human granulocyte colony-stimulating factor: Biologic activities and receptor characterization on hematopoietic cells and small cell lung cancer cell lines. Blood 75(4): 851-857, 1990. PMID: 1689190.

27 Oka Y, Kobayashi T, Fujita S, Matsuura N, Okamoto S, Asakawa $\mathrm{H}$, Murata A and Mori T: Establishment of a human anaplastic thyroid cancer cell line secreting granulocyte colony-stimulating factor in response to cytokines. In Vitro Cell Dev Biol Anim 29A(7): 537-542, 1993. PMID: 7689076. DOI: 10.1007/BF02 634147

28 Young MR, Wright MA, Lozano Y, Prechel MM, Benefield J, Leonetti JP, Collins SL and Petruzzelli GJ: Increased recurrence and metastasis in patients whose primary head and neck squamous cell carcinomas secreted granulocyte-macrophage colonystimulating factor and contained CD34+ natural suppressor cells. Int J Cancer 74(1): 69-74, 1997. PMID: 9036872. DOI: 10.1002/(sici)1097-0215(19970220)74:1<69::aid-ijc12>3.0.co;2-d

Received December 20, 2020

Revised February 16, 2021

Accepted March 22, 2021 